\title{
WORKFARE AND TRADE UNIONS: LABOR MARKET REPERCUSSIONS OF WELFARE REFORM
}

\author{
RONNIE SCHÖB
}

CESIFo WORKING PAPER No. 942

CATEgORY 1: Public FinANCE

MAY 2003

\footnotetext{
An electronic version of the paper may be downloaded

- from the SSRN website: www.SSRN.com

- from the CESifo website: www.CESifo.de
} 


\title{
WORKFARE AND TRADE UNIONS: LABOR MARKET REPERCUSSIONS OF WELFARE REFORM
}

\begin{abstract}
Workfare proposals concentrate on the work incentives for welfare recipients, thus focusing on the labor supply side. This paper analyzes the effects workfare has on labor demand when the labor market is unionized. As workfare reduces the number of recipients of public financial assistance, a workfare regime, as opposed to a welfare system, weakens the outside option of trade unions in wage negotiations. It is shown that revenue-neutral workfare enforcement where any surpluses are rebated by i) reducing the income tax or ii) increasing a workers' tax credit, unambiguously decreases gross wage rates and thus decreases equilibrium unemployment. Though trade union members may be worse off as a consequence of workfare enforcement, their compensation for the wage reduction is highest when the revenue-neutral rebate of savings is used to increase worker-specific tax credits.
\end{abstract}

JEL Code: E60, H53, J51.

Keywords: workfare, welfare reform, trade unions, involuntary unemployment.

Ronnie Schöb

Faculty of Economics and Management

Otto-von-Guericke University Magdeburg

P.O.Box 4120

39106 Magdeburg

Germany

ronnie.schoeb@ww.uni-magdeburg.de 


\section{Introduction}

The subsystems of welfare states aiming at the alleviation of poverty have come under attack. In many European countries such as France or Germany, maintaining a subsistence level of income is still the primary objective, but there is also a growing consensus that the systems should move towards a system such as e.g. the "Earned Income Tax Credit" in the United States which rewards additional household income. The main idea of these "workfare" or, synonymously, "welfare-to-work" type of programs is to reward work instead of unemployment by granting public monetary assistance only for those who are willing to work. The promise of these workfare proposals is to overcome the poverty trap and to increase labor supply. In addition, it is argued that those who are willing to work enjoy some non-pecuniary advantages such as increased self-esteem, a reduction in stigmatization as a jobless person and the (re-)learning of certain basic skills, which are essential for competing for ordinary jobs. ${ }^{1}$ Last but not least, these programs allow the government to reduce public expenditures for welfare programs while retaining a broad social consensus.

The existing literature on workfare almost entirely neglects the effects workfare may have on the labor demand side. In economies with unionized labor markets, however, it is necessary to determine the effects on labor demand rather than labor supply because the labor demand falls short of labor supply due to too high wage costs thus causing unemployment. This paper therefore focuses on the repercussions of workfare schemes on the wage determination in unionized labor markets.

Our analysis shows that in an economy where trade unions determine the wage rate in their sectors and the firms then determine employment, a workfare system, as opposed to a welfare system, weakens the outside option of the trade union in the wage negotiations. Therefore, wages tend to decrease and unemployment to fall. Furthermore, as less individuals are in need of public assistance, the budget surplus generated by the workfare regime can be used for further labor market policy measures.

\footnotetext{
${ }^{1}$ See e.g. Clark and Oswald (1994), Winkelmann and Winkelmann (1995) and Gerlach and Stephan (1996).
} 
Two complementary policy measures will be included into our analysis, namely a revenue-neutral cut in the income tax rate and, alternatively, a revenue-neutral rise in the workers' tax credit. It is shown that the latter is both more efficient with respect to promoting employment and less harmful for trade unions. Their members become partially compensated for the wage reductions. This may reduce the political resistance of trade unions to any kind of workfare regime.

The main feature of workfare programs we focus on in this paper is the selection principle, which means that the obligation to work separates the truly needy out of the pool of welfare recipients (Besley and Coate 1992). Empirically, one of the most visible effects of the program is a dramatic reduction in the number of beneficiaries. Cancian et al. (2000) shows for the USA that among those who left the welfare program, about two thirds entered a job, while one third remained without. Thus welfare programs become less expensive after the reform than before, with average annual cost decreases for the respective programs of $6.3 \%$ in the U.S. as a whole and $9.1 \%$ in Wisconsin where a specific workfare program, called "Wisconsin Works" was established. ${ }^{2}$

The paper is organized as follows. Section 2 describes the selection principle of workfare and shows how it can be applied for the analysis of the impact a reform of the welfare system towards a workfare system will have on wage determination. Section 3 introduces a monopoly trade union model where trade unions set wages in their sectors and firms then determine employment. Within this analytical framework, we will show how a piecemeal move towards a workfare system changes the equilibrium wage rate in the economy. Section 4 then compares the efficiency of two alternative complementary policy measures, which make use of the budget surplus generated by the workfare scheme. Section 5 , by contrast, focuses on the distributional consequences. Implications for economic policy will be presented in the concluding Section 6. For the sake of the clarity of the argument, most of the calculations are presented in the Appendix.

\footnotetext{
${ }^{2}$ According to the Congressional Research Service (2000, p. 407), between 1995 and 1999 expenditure for welfare in the USA has gone down by $27.8 \%$ while in Wisconsin the reduction was $41.6 \%$. Given the decline of $73.6 \%$ in the number of welfare recipients in Wisconsin in the same period, the savings in total welfare expenditure might even have been much higher, had they not been partly offset by increasing welfare payments and administrative expense per family.
} 


\section{From welfare to workfare}

The idea of workfare is to replace the existing welfare system, in which payments are made unconditionally to all welfare recipients, by a mutual contract in which welfare payments are granted only conditionally upon a service rendered in return by the recipient. The required work, which may be a job in the private sector or, alternatively, in a public job creation company, serves as a selection mechanism, which ensures that only truly needy persons actually obtain public transfers. In this section we illustrate the selection mechanism of a workfare scheme by using a simplified version of the Besley and Coate (1992) model. Thereby, we modify the model in a way that allows us to analyze the effect of workfare on wage determination and labor demand, respectively.

In the economy, there are $N$ workers each supplying one unit of labor in the labor market. $L \leq N$ workers are employed in the primary labor market, $N-L$ workers are registered as being unemployed and entitled to receive unemployment benefit payments $b^{u}$. All workers are identical with respect to their working abilities. However, when unemployed, we distinguish two types of workers, which differ with respect to their access to non-market income of $b^{n}$. The share $s$ of all workers has no access to non-market income and must entirely rely on the public unemployment benefit payments $b^{u}$ when becoming unemployed. By contrast, $(1-s) N$ workers have access to non-market labor income when unemployed. The government cannot observe non-market income. Thus, in a pure welfare regime, there are $s(N-L)$ unemployed workers who entirely rely on welfare benefit payments while $(1-s)(N-L)$ unemployed workers obtain both unemployment benefit payments and nonmarket income. Throughout the paper we assume that working in the primary labor market is always preferred to working in the non-market sector.

Figure 1 shows the budget constraint for workers with access to non-market income. Hours worked in the non-market sector are measured on the horizontal axis, while total income is measured on the vertical axis. Those with access to non-market income face an upward sloping budget line, starting in $b^{u}$. Given their preferences ${ }^{3}$ with respect to income and leisure, workers with access to non-market activities work $T$ hours, adding a non-market

\footnotetext{
${ }^{3}$ In Figure 1 we assume a quasi-linear utility function.
} 
income of $b^{n}$ to the unemployment benefit payment $b^{u}$ they receive. Thus, their total income is $b^{u}+b^{n}$. The utility when working, $u\left(b^{u}+b^{n}, T\right)$ exceeds that of non-working, $u\left(b^{u}, 0\right)$. Those who have no access to non-market income face a horizontal budget line. Their income is $b^{u}$.

Figure 1: The selection mechanism of workfare

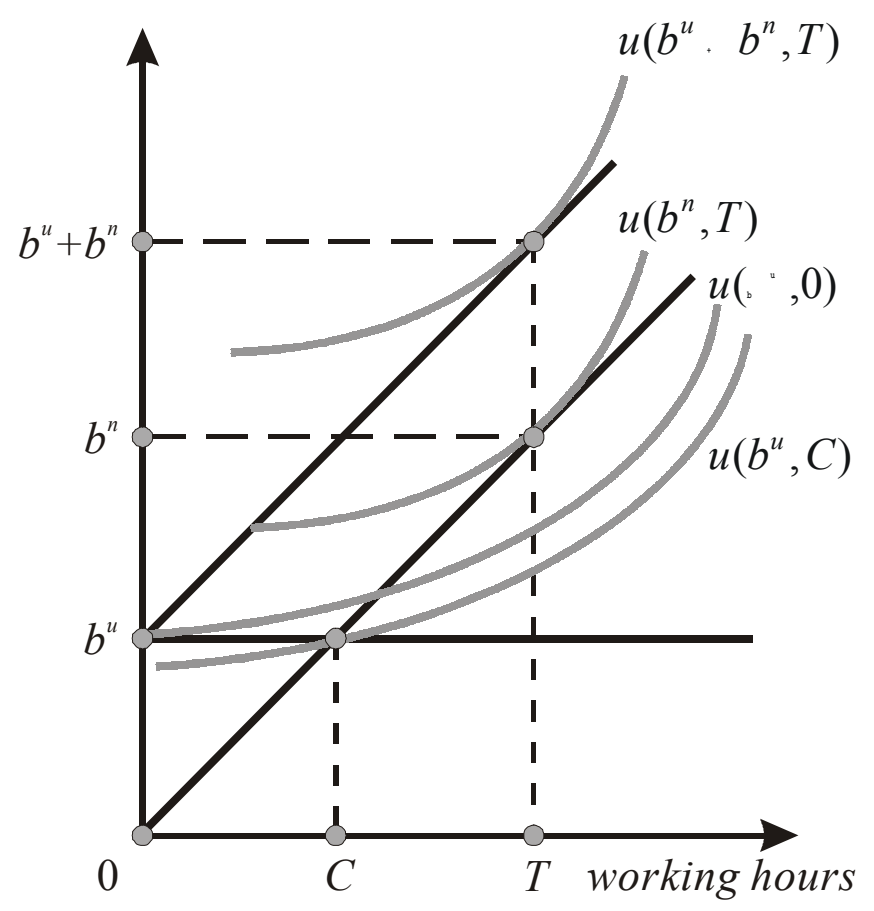

If the government requires that, in order to qualify for the unemployment benefit payment, each welfare recipient has to work $C$ hours in e.g. a public job creation company, those without access to non-market income accept the workfare scheme. Their utility decreases from $u\left(b^{u}, 0\right)$ to $u\left(b^{u}, C\right)$, but they are better off compared to the alternative not to work in the public job creation company, and consequently losing their unemployment benefit payments. By contrast, those unemployed workers with access to non-market income are indifferent between staying and leaving the workfare regime as their budget constraint shifts rightwards, now starting at the point $\left(b^{u}, C\right)$. However, compared to the situation without a workfare program, they are worse off by the amount of $u\left(b^{u}+b^{n}, T\right)-u\left(b^{n}, T\right)$. If the required working time exceeded $C$, they would leave the workfare scheme because the implicit hourly wage falls short of the non-market hourly remuneration. If the time required to stay in the public job creation company falls short of $C$, they would join the workfare 
program. Note that if the government considers $b^{u}$ as the minimum income level, workfare makes sense only if $b^{n}>b^{u}$. Both types of unemployed are worse off in a workfare system.

If the government could perfectly enforce a workfare regime, which requires all unemployed benefit recipients to work $C$ hours, the expected welfare payments would be reduced by $(1-s) b^{u}$. However, the government normally cannot introduce a comprehensive workfare scheme because of administrative obstacles such as the lack of sufficient job opportunities available in job creation companies. Let $\alpha$ measure the degree of workfare enforcement, then the average income of an unemployed worker, $b^{a}$, is given by:

$$
b^{a}=\alpha\left(s b^{u}+(1-s) b^{n}\right)+(1-\alpha)\left(b^{u}+(1-s) b^{n}\right)=(1-\alpha(1-s)) b^{u}+(1-s) b^{n} .
$$

With probability $\alpha$ an unemployed worker has to participate in a workfare scheme, with probability $(1-\alpha)$ he can stay in the traditional welfare scheme. In the former case, only the share $s$ of all unemployed workers receives the unemployment benefit payments while in the latter case, all unemployed workers do. Independently of what regime prevails, $(1-s)(N-L)$ unemployed workers receive the non-market income $b^{n}$.

Equation (1) denotes the expected income of an unemployed worker as a function of the degree of workfare enforcement $\alpha$. As the degree of enforcement increases, the average unemployment income decreases:

$$
\frac{\partial b^{a}}{\partial \alpha}=-(1-s) b^{u}<0
$$

Having determined the expected income of a worker who becomes unemployed, we can now turn to the trade union's decision problem.

\section{The monopolized labor market}

We consider the labor market of a small open economy with $I$ sectors. Each sector is perfectly specialized in the production of good $X^{i}, i=1, \ldots, I$, which is completely exported and sold on the world market at a world market price normalized to unity. In each sector of the economy labor supply is given by $N^{i}$, and all workers are organized in a sector-wide operating trade 
union. Sector $i$ produces output $X^{i}$ with labor $L^{i}$ as the only variable input. The production function is strictly concave, i.e. $X^{i}=f\left(L^{i}\right), f_{L}>0, f_{L L}<0$. As each firm considers both the wage rate and the producer price as given, it maximizes profit with respect to labor input. Profit maximization yields the labor demand function $L^{i}=L\left(w^{i}\right)$ with $L_{w}^{i}<0$. For technical convenience, in what follows we assume that the wage elasticity of labor demand $\eta^{i}=w L_{w}^{i} / L^{i}<-1$ is constant. ${ }^{4}$ Furthermore, instead of modeling wage bargaining between a trade union and the firms explicitly, we focus on a monopoly trade union model, as this model derives the same qualitative results as the "right-to-manage" bargaining model for those variables that affect the trade union objective only (cf. Holmlund, Löfgren and Engström 1989).

The objective of the monopoly trade union is to maximize its members' income, which consists of the net-of-tax wage income and the expected net-of-tax unemployment income. As each worker inelasticly supplies one unit of labor if employed, or zero labor if unemployed, the net-of-tax wage income depends on the gross wage rate $w$, the income tax $t$, and the personal tax credit $a$ which is granted to each tax payer, i.e. $w(1-t)+a$.

Trade union members who do not find a job in their sector $i$ will not necessarily become unemployed. With a probability equal to the economy wide employment rate $(1-u)$, with $u$ denoting the economy-wide unemployment rate, they will find a job in another sector earning the expected average gross wage rate $\bar{w}$. With probability $u$ they become unemployed and are thus receiving on average (from the viewpoint of the trade union) the unemployment income as given by equation (1). Following Layard, Nickell and Jackman (1991), we assume that the unemployment benefit payments are proportionate to the expected net-of-tax wage income in the economy, i.e.

$$
b^{u}=\gamma(\bar{w}(1-t)+a) \text {. }
$$

\footnotetext{
${ }^{4}$ This production function implicitly assumes that there is some fixed factor, e.g. capital, leading to decreasing marginal productivity of labor. Assuming a Cobb-Douglas production technology, e.g., guarantees a constant labor demand elasticity.
} 
The non-market income, by contrast, is not related to the gross wage rate in the primary sector and is exogenously given in what follows. Substituting equation (3) in (1), the opportunity cost of working in the own sector is given by

$$
b^{i}=(1-u)(\bar{w}(1-t)+a)+u b^{a}=(1-u(1-\gamma(1-\alpha(1-s))))(\bar{w}(1-t)+a)+u(1-s) b^{n} .
$$

Having analyzed the different real income components, we can specify the objective function of the trade union, which can be written as ${ }^{5}$

$$
V^{i}=\left(w^{i}(1-t)+a\right) L^{i}+b^{i}\left(N^{i}-L^{i}\right) .
$$

The first-order condition with respect to the gross wage rate $w$ is given by:

$$
V_{w}^{i}=0=\left(1-t_{L}\right) L^{i}+\left(w^{i}\left(1-t_{L}\right)+a-b^{i}\right) L_{w}^{i} .
$$

Note that from the viewpoint of the trade union, the reservation wage $b^{i}$ is exogenously determined. Taking account of the labor demand of the firms in sector $i$ and using the elasticity of labor demand, the gross wage rate in sector $i$ is implicitly given by:

$$
w^{i}(1-t)(1+\eta)+\left(a-b^{i}\right) \eta=0 .
$$

Condition (6) reveals that the workers' tax credit must be smaller than the opportunity cost of working in this sector (4), $a-b^{i}<0$, to obtain an interior solution. Otherwise the trade union would always ensure that full-employment is established in the sector. In what follows, we focus on the case where the workers' tax credit is smaller than the unemployment benefit payment $b^{u}$ as empirically the tax credit is only a small proportion of the net-of-tax labor income while the replacement ratio $\gamma$ normally exceeds 50\% (cf. Nickell and Layard, 1999). Thus, we have $a<b^{u} \leq b^{a} \leq b^{i}$.

Following Layard, Nickell and Jackman (1991) we consider the symmetric case where all sectors exhibit the same production function and face the same labor supply $N^{i}$. Thus, in equilibrium all sectors will face the same marginal productivity of labor and the gross wage rate is the same everywhere, $w^{i}=\bar{w} \equiv w \forall i$. Aggregate labor supply is given by $I \cdot N^{i}=N$

\footnotetext{
${ }^{5}$ The use of a linear objective function is for analytical convenience. Alternatively, without changing the qualitative results, we could assume that the trade union maximizes the expected utility of its representative worker, taking into account the risk aversion of its members.
} 
and aggregate employment by $I \cdot L^{i}=L$. Substituting equation (4) in (6), we can solve for the aggregate equilibrium unemployment rate $u$ (using $\eta=\eta^{i}$ )

$$
u \equiv \frac{N-L}{N}=-\frac{w(1-t)}{\left[(1-\gamma(1-\alpha(1-s)))(w(1-t)+a)-(1-s) b^{n}\right] \eta} .
$$

Note first that if there is no tax credit $a$ available for workers and there are no non-market opportunities to raise the expected unemployment income, i.e. $a=b^{n}=0$, the unemployment rate (7) is independent of the labor tax rate. In this case, there is also no scope for the government to apply the separating device of a workfare regime. Thus,

$$
\left.u\right|_{a=b^{n}=0}=-\frac{1}{(1-\gamma) \eta} .
$$

The result, that the unemployment rate is independent of the tax rate, confirms a frequently quoted result that, in the long run, the labor tax burden is completely shifted onto workers. However, in the presence of a progressive tax structure - due to the tax credit the average tax rate falls short of the marginal tax rate - and some unemployment income components, which are not proportionate to the gross wage rate, the labor tax rate does affect the aggregate unemployment rate even in the long run (cf. Schöb 2000). This result is in line with recent empirical studies of the effects of labor taxes on unemployment (cf. Layard and Nickell 1999, Daveri and Tabellini 2000, Reutter 2001). Thus, it is important to not only analyze the direct effect workfare has on wage determination but to also take account of how the other control variables of the government affect the aggregate unemployment rate. We therefore proceed in two steps. We first analyze how cet. par. workfare enforcement affects wage determination and employment. Then, in the next section, we analyze the overall effect of revenue-neutral workfare enforcement when the budget surplus generated by the workfare enforcement is rebated.

The gross wage rate reacts to changes in the degree of workfare enforcement $\alpha$, the tax rate $t$ and the personal tax credit $a$. The calculations are presented in Appendix 1. With respect to workfare enforcement, the gross wage is unambiguously negative, i.e. 


$$
\begin{gathered}
-9- \\
\frac{d w}{d \alpha}<0 .
\end{gathered}
$$

Increasing the degree of workfare enforcement reduces the gross wage rate set by the monopoly trade union. It works in the same way as a reduction in the replacement ratio $\gamma$. The average income of an unemployed worker falls as fewer unemployed workers receive the nonmarket income $b^{n}$. This weakens the outside option of the trade union as it raises the wage surplus, lost by those laid off due to a wage increase. At the same time, the benefit for the incumbent workers remains unaffected. It becomes thus profitable for the union to accept a lower gross wage. Thus aggregate employment increases.

PROPOSITION 1: Enforcing workfare cet. par. lowers the equilibrium gross wage rate in an economy with unionized labor markets and promotes labor demand.

\section{Revenue-neutral workfare enforcement}

As shown in Section 2, enforcing workfare reduces public expenditures for unemployment benefit payments. This allows the government to either reduce the (uniform) income tax rate $t$ or to increase the tax credit $a$. The public budget is given by

$$
t(w L+\pi)-a L-(1-\alpha(1-s)) b^{u}(N-L)=R,
$$

where $\mathrm{R}$ denotes a predetermined level of public revenues needed to finance some public goods. The first term indicates the income tax revenues, the second term denotes the expenditures for the workers' tax credit and the third term denotes the expenditures for the public unemployment benefit system. For simplicity we abstract from both cost of workfare enforcement and revenues generated in public job creation companies. Substituting in the long-run relationship for the unemployment benefit payments (3), we can rewrite the budget constraint as

$$
t(w L+\pi)-a L-(1-\alpha(1-s)) \gamma(w(1-t)+a)(N-L)=R .
$$


As shown in Appendix 2, the direct effect of enforcing workfare generates a surplus, $R_{\alpha}=(1-s) b^{u}(N-L)>0$ [cf. equation (2)]. Furthermore, the induced effect of a lower gross wage rate also generates a surplus as we have $R_{w}<0$. The total effect of workfare enforcement on the budget surplus is thus unambiguously positive:

$$
\frac{d R}{d \alpha}=R_{\alpha}+R_{w} \frac{d w}{d \alpha}>0
$$

The budget surplus exceeds the savings from reduced unemployment benefit payments as tax revenues are increasing in employment. This budget surplus can be used to either reduce the income tax rate $t$ or to increase the tax credit $a$. For any revenue-neutral reform the following condition must hold:

$$
d R=0=\left(R_{\alpha}+R_{w} \frac{d w}{d \alpha}\right) d \alpha+\left(R_{t}+R_{w} \frac{d w}{d t}\right) d t+\left(R_{a}+R_{w} \frac{d w}{d a}\right) d a
$$

In what follows we analyze the two cases where either only the income tax, $d a=0$, or the tax credit, $d t=0$, is altered. Assuming that the tax system is Laffer-efficient, i.e. $R_{t}+R_{w} d w / d t>0$ and $R_{a}+R_{w} d w / d a<0$, the change in the income tax rate and the tax credit, respectively, follows immediately from (10) and (11).

$$
\left.\frac{d t}{d \alpha}\right|_{\substack{d R=0 \\ d a=0}}<0,\left.\quad \frac{d a}{d \alpha}\right|_{\substack{d R=0 \\ d t=0}}>0
$$

Next, we turn to the comparative statics results. As is shown analytically in the Appendix 1, a change in the income tax rate has an ambiguous effect on gross wages. If the workers' tax credit is zero, increasing the income tax rate leads to a higher gross wage rate. In this case, an increase in the income tax reduces the net-of-tax wage rate relatively more than the outside option $b^{i}$. However, if the parts of the outside option that are not proportional to the gross wage become negative - this is the case when the tax credit becomes large relative to the nonmarket income - the opposite result may occur.

Empirical estimates about the long-run effects of changes in the labor tax wedge indicate that the unemployment rate (and therefore the gross wage rate) is increasing in the labor tax rate. Nickell and Layard (1999, p. 3053) regress the log unemployment rate on the 
total labor tax wedge (among a variety of controls) in a cross-country study with 20 OECD countries over two five-years periods and find that a one-percentage point increase of the labor tax rate would reduce unemployment by 0.27 percentage points. Daveri and Tabellini (2000) argue that the effects of tax rate changes on unemployment differ between different OECD countries. While they did not find any significant effect for countries like the US, Japan or the Scandinavian countries, the tax wedge effect is more pronounced than reported in Nickell and Layard (1999) in countries like Australia, Belgium, France, Germany, Italy, the Netherlands and Spain. They regress the standardized unemployment rate on the effective tax rate on labor income and report a labor tax coefficient between 0.29 and 0.54 (see their Table 9, p.75).

If the budget surplus of workfare enforcement is used to cut the income tax rate, the total effect of a revenue-neutral workfare enforcement is given by:

$$
\left.\frac{d w}{d \alpha}\right|_{\substack{d R=0 \\ d a=0}}=\frac{d w}{d \alpha}+\left.\frac{d w}{d t} \frac{d t}{d \alpha}\right|_{\substack{d R=0 \\ d a=0}}<0 .
$$

The first term of the right-hand side covers the direct effect as described in the last section. A revenue-neutral enforcement of workfare allows the government to lower the income tax. In the empirically relevant case $d w / d t>0$, the direct effect is reinforced by the induced cut in the income tax rate. Both workfare enforcement and the reduced income tax rate lead the trade unions to lower wages. But even if the indirect effect works in the opposite direction, the overall effect still remains negative (cf. Appendix 3). Proposition 2 summarizes.

PROPOSITION 2: Revenue-neutral workfare enforcement that lowers the income tax rate, lowers the equilibrium gross wage rate in an economy with unionized labor markets and thus increases employment.

The comparative statics for the workers' tax credit (cf. Appendix 1) shows that the gross wage rate is unambiguously decreasing in the workers' tax credit:

$$
\frac{d w}{d a}<0 .
$$


An increase in the workers' tax credit $a$ can be interpreted as a subsidy on labor. A higher labor subsidy induces the trade union to accept a lower wage rate as the marginal worker can now gain more from working than those already employed will lose from the necessary wage reduction. The total effect of a revenue-neutral workfare enforcement, which increases the workers' tax credit, is given by

$$
\left.\frac{d w}{d \alpha}\right|_{d R=0} ^{d R=0}=\frac{d w}{d \alpha}+\left.\frac{d w}{d a} \frac{d a}{d \alpha}\right|_{d t=0}<0
$$

As in the case of lowering the income tax, the increase of the workers' tax credit reinforces the direct effect of workfare enforcement due to lower average unemployment benefit payments. Proposition 3 summarizes.

PROPOSITION 3: Revenue-neutral workfare enforcement that increases the workers' tax, credit lowers the equilibrium gross wage rate in an economy with unionized labor markets and thus increases employment.

Though the Propositions 2 and 3 show qualitatively the same effect on the gross wage rate and employment, the effects may differ quantitatively. To identify the more efficient reform with respect to alleviating unemployment, let us consider the case where the government has already rebated the budget surplus by reducing the income tax rate but now reverses the reduction of the income tax and increases the workers' tax credit instead. This can be interpreted as an increase in tax progression. As shown formally in Appendix 4, we have

$$
\left.\frac{d w}{d a}\right|_{d R=0}=\frac{d w}{d a}+\left.\frac{d w}{d t} \frac{d t}{d a}\right|_{d R=0}=\frac{R_{a}\left[w g_{a}+g_{t}\right]-\pi \frac{g_{a}}{g_{w}}}{\left[-R_{w} \frac{g_{t}}{g_{w}}-w R_{a}+\pi\right] g_{w}}<0 .
$$

Both terms of the numerator of the right-hand side are negative. The second term covers the fact that the increase in the workers' tax credit is partly financed by increasing the tax on profit income. This lowers the tax burden on labor and thus lowers the gross wage rate. However, even if the tax revenues from profit taxation did not change, increasing the workers' tax credit, financed by an increase in a pure labor tax rate, would lower the gross 
wage rate. This is covered by the first term. Intuitively, an increase in tax progression moderates wages because it acts as a penalty on wage increases. While the average tax burden on labor is kept constant, the arbitrage condition of the monopoly trade union changes as the incumbent workers benefit less from a wage increase the higher the (marginal) labor tax rate is. As the cost of a wage increase does not change at the margin, the monopoly trade union will lower the wage rate. This result confirms the analysis of Koskela and Vilmunen (1996) who have shown that a more progressive tax system will go along with higher employment in popular models of trade union behavior including the monopoly trade union model. The effect is strengthened though by the fact that a higher uniform tax rate on income allows the government to obtain more revenues from non-distorting profit taxation.

PROPOSITION 4: Increasing the workers' tax credit is more effective in promoting employment than reducing the income tax rate.

So far we have focused on the efficiency aspects of workfare enforcement. Now we turn to the politically important question about the distributional consequences workfare enforcement will have.

\section{Distributional considerations}

Enforcing workfare lowers the opportunity cost of working in the own sector, $b^{i}$, and thus the bargaining position of the trade union. As a consequence, the trade union members will be worse off as we have $V_{b^{i}}<0$. However, as discussed in the previous section, enforcing workfare induces effects on the gross wage rate and aggregate employment and allows the government to either reduce the income tax or increase the workers' tax credit. As the latter is more efficient in raising employment it is interesting to analyze whether this is also favorable with respect to minimizing the redistributive consequences of workfare enforcement. The lower the distributive effects are the higher the political acceptance of workfare would be in an economy with unionized labor markets.

To analyze the question we first compare the change in the trade union objective function when workfare enforcement is accompanied by a revenue-neutral increase in the 
workers' tax credit with the change when workfare enforcement is accompanied by a revenueneutral cut in the income tax. Analytically, we look at the difference

$$
\left.\frac{d V}{d \alpha}\right|_{\substack{d R=0 \\ d t=0}}-\left.\frac{d V}{d \alpha}\right|_{\substack{d R=0 \\ d a=0}}>0 .
$$

As is shown in Appendix 5, the difference is unambiguously positive. There are three reasons for this result. Firstly, increasing the workers' tax credit ensures that rebating the budget surplus benefit workers only. By contrast, any reduction of the income tax would benefit both labor income and profits. Secondly, as profits increase in employment additional tax revenues from profit taxation are generated which are returned to the workers. Thirdly, even in the absence of the first two effects, rebating the budget surplus via an increase in the workers' tax credit is always more beneficial to the trade union, because it ensures that for any given level of public unemployment benefit payments and workfare enforcement, more members are employed in the primary labor market. Thus, political resistance of trade unions against workfare schemes can be reduced when the budget surplus generated by a move towards a workfare scheme is handed back to workers only by increasing specific worker tax credits. The following proposition summarizes this finding.

PROPOSITION 5: Increasing the workers' tax credit minimizes the loss accruing to trade union members due to workfare enforcement.

\section{Concluding remarks}

The last decade saw a growing number of labor market reforms that aim at promoting workfare. The idea of all these proposals is to warrant work instead of unemployment. This can alleviate the unemployment of those caught in the poverty trap where it is individually rational not to work. As long as the labor market is sufficiently flexible to offer jobs to those who supply labor, successful workfare programs will boost employment and reduce the cost of the welfare state. However, in countries suffering from unemployment due to unionized 
labor markets, promoting labor supply cannot be sufficient to also promote employment, since in economies with unionized labor markets the labor market is rationed by the labor demand. In this paper we show how the introduction of a workfare scheme will affect labor demand. As workfare reduces the number of recipients of public financial assistance, a workfare regime, as opposed to a welfare system, weakens the outside option of trade unions in wage negotiations and consequently moderates wages and boosts employment.

As trade union members are worse off as a consequence of workfare enforcement, it is likely that trade unions will strictly oppose the idea of moving the system of welfare to a system of workfare. It is thus important to see which complementary measures can be undertaken to lower the potential resistance of trade unions. One way to at least partially compensate workers is to rebate savings in welfare expenditures in a way that benefit workers only.

One important insight of our analysis is that there is a combination of instruments, i.e. introducing workfare and increasing workers tax credit, that is preferable both in terms of efficiency and minimal distributional consequences. The efficiency result confirms the analysis of Koskela and Vilmunen (1996) who have shown that a more progressive tax system tends to increase employment, as for any given average tax rate on labor, a higher marginal tax rate works like a penalty on wage increases. Thus, any revenue surpluses should be rebated in a way that increases rather than decreases tax progression. In our framework this can be achieved by raising the worker-specific tax credit. This policy is even more efficient, as the alternative, lowering income tax, would imply that the non-distorting profit tax will be lowered.

The analysis of the distributional consequences then proved in the case of a workfare reform that the more efficient instrument turns out to also be the less harmful instrument for those likely to be the losers of the reform. For workers, higher worker-specific tax credits are favorable to cuts in income taxes for three reasons. First, increasing the worker-specific tax credit benefits workers only. Second, the higher the income tax rate the more additional tax revenues are generated from profit taxation when employment and thus profits rise. Finally, and most important, rebating the budget surplus via an increase in the tax credit is always 
more beneficial to the trade union, because it ensures that for any given level of public unemployment benefit payments and workfare enforcement, more members are employed in the primary labor market.

In a time where the ongoing fight between unions and capital owners about the distribution of the domestic product apparently paralyzes all attempts to reform the labor market, it may be considered good news that there are still some policy options available that alleviate the distributive consequences to an extent that may overcome the reform holdup many European countries are trapped in.

\section{Appendix 1: comparative statics}

To analyze how the gross wage rate reacts to changes in the degree of workfare enforcement, the tax credit, and the tax rate, we define an implicit function $g$

$$
g \equiv(N-L) \frac{\left[(1-\gamma(1-\alpha(1-s)))(w(1-t)+a)-(1-s) b^{n}\right]}{w(1-t)}+\frac{N}{\eta}=0 .
$$

The partial derivatives of $\mathrm{g}$ with respect to $\alpha, a, t$ are:

$$
\begin{gathered}
g_{\alpha}=(N-L) \frac{\gamma(1-s)(w(1-t)+a)}{w(1-t)}>0 . \\
g_{a}=(N-L) \frac{(1-\gamma(1-\alpha(1-s)))}{w(1-t)}>0 . \\
g_{t}=(N-L) \frac{(1-\gamma(1-\alpha(1-s))) a-(1-s) b^{n}}{w(1-t)^{2}} .
\end{gathered}
$$

The sign of a change in the income tax depends on the relationship between personal tax credit and the non-market income of unemployed workers and is a priori. The numerator equals the part of the outside option that isn't proportional to the wage rate as can be seen from rewriting (4) in the following way

$$
b^{i}=a+(1-u(1-\gamma(1-\alpha(1-s)))) \bar{w}(1-t)+u\left((1-s) b^{n}-(1-\gamma(1-\alpha(1-s))) a\right) .
$$

If the workers' tax credit is zero, this component is positive, (A4) becomes negative while a positive tax credit together with $b^{n}=0$ leads to a positive sign. and an increase in the income 
tax rate increases the gross wage rate. The reason is that, in this case, an increase in the income tax reduces the net-of-tax wage rate by more than the outside option $b^{i}$. Only if the non-proportional component becomes negative, the opposite result may occur. ${ }^{6}$

Finally, partial differentiation of $g$ with respect to the gross wage rate yields:

$$
\begin{aligned}
g_{w}= & -L_{w} \frac{\left[(1-\gamma(1-\alpha(1-s)))(w(1-t)+a)-(1-s) b^{n}\right]}{w(1-t)} \\
& +(N-L) \frac{-(1-\gamma(1-\alpha(1-s))) a+(1-s) b^{n}}{w^{2}(1-t)} .
\end{aligned}
$$

(A5) can be rewritten as:

$$
\begin{aligned}
g_{w} & =\frac{-L}{w^{2}(1-t)}\left(\eta+\frac{(N-L)}{L}\right)\left[(1-\gamma(1-\alpha(1-s)))(w(1-t)+a)-(1-s) b^{n}\right] \\
& +\frac{(N-L)}{w^{2}(1-t)}(1-\gamma(1-\alpha(1-s))) w(1-t) .
\end{aligned}
$$

The second term is always positive. As long as $N<2 L$, i.e. the unemployment rate is below $50 \%$, the first term is also positive as $\eta<-1$. Hence, $g_{w}>0$. The effect of changes in the workfare enforcement, the tax credit and the income tax rate respectively on the gross wage rate is given by the condition:

$$
g_{j} d j+g_{w} d w=0, \quad j=\alpha, a, t
$$

Using the signs derived above, we can immediately determine the sign of

$$
\frac{d w}{d j}=-\frac{g_{j}}{g_{w}}, \quad j=\alpha, a, t .
$$

\section{Appendix 2: marginal tax revenues}

Partial derivatives of the budget constraint (9) yield:

$$
\begin{aligned}
& R_{\alpha}=\gamma(1-s)(w(1-t)+a)(N-L)>0, \\
& R_{a}=-L-\gamma(1-\alpha(1-s))(N-L)<0,
\end{aligned}
$$

\footnotetext{
${ }^{6}$ Note that the first term of the right-hand side does not matter for this argument. Substituting in the formulation $\left(4^{*}\right)$ into the objective function (5) shows that that the workers' tax credit $a$ can be decomposed into a lump-sum subsidy to all $N^{i}$ workers and a negative unemployment benefit component equal to $(1-\gamma(1-\alpha(1-s))) a$.
} 


$$
R_{t}=f(L)+\gamma(1-\alpha(1-s)) w(N-L)=\pi-w R_{a}>0,
$$

and, using $w L+\pi=f(L)$, and $f_{L}=w$ :

$$
R_{w}=-\gamma(1-\alpha(1-s))(1-t)(N-L)+\left[t w-a+(1-\alpha(1-s)) \gamma((w(1-t)+a)] L_{w} .\right.
$$

The first term is negative. Assuming that the average tax burden on labor is positive, i.e. $t w-a>0$, the term in square brackets is positive and thus the second term is also negative.

\section{Appendix 3: reducing the income tax}

From (12) we have

$$
\begin{aligned}
\left.\frac{d w}{d \alpha}\right|_{\substack{d R=0 \\
d a=0}} & =\frac{d w}{d \alpha}+\left.\frac{d w}{d t} \frac{d t}{d \alpha}\right|_{\substack{d R=0 \\
d a=0}}=-\frac{g_{\alpha}}{g_{w}}-\frac{g_{t}}{g_{w}}\left[-\frac{R_{\alpha}+R_{w} \frac{d w}{d a}}{R_{t}+R_{w} \frac{d w}{d t}}\right]=-\frac{g_{\alpha}}{g_{w}}+\frac{g_{t}}{g_{w}}\left[\frac{R_{\alpha}-R_{w} \frac{g_{\alpha}}{g_{w}}}{R_{t}-R_{w} \frac{g_{t}}{g_{w}}}\right] \\
& =\frac{1}{R_{t} g_{w}-R_{w} g_{t}}\left[R_{\alpha} g_{t}-R_{t} g_{\alpha}\right] .
\end{aligned}
$$

As the first term is positive, we can focus on the sign of the expression in square brackets. Substituting in (A2), (A4), (A8) and (A10), we obtain, after some calculations:

$$
\begin{aligned}
& R_{\alpha} g_{t}-R_{t} g_{\alpha}=\frac{R_{\alpha}(N-L)}{w(1-t)^{2}}\left[a-\gamma(1-\alpha(1-s))(w(1-t)+a)-(1-s) b^{n}-f(L)(1-t)\right] \\
& =\frac{R_{\alpha}(N-L)}{w(1-t)^{2}}\left[a-(1-\alpha(1-s)) b^{u}-(1-s) b^{n}-f(L)(1-t)\right] \\
& =\frac{R_{\alpha}(N-L)}{w(1-t)^{2}}\left[a-b^{a}-f(L)(1-t)\right] .
\end{aligned}
$$

As $a-b^{a}<0$, we have $R_{\alpha} g_{t}-R_{t} g_{\alpha}<0$ and therefore the sign as indicated in (14).

\section{Appendix 4: a change in tax progression}

From (11), using (A7) to describe the indirect effect of a revenue-neutral tax reform that increases both the workers' tax credit and the income tax, we obtain the following condition

$$
\left.\frac{d t}{d a}\right|_{d R=0}=-\frac{R_{w} \frac{d w}{d a}+R_{a}}{R_{w} \frac{d w}{d t}+R_{t}}=\frac{R_{w} \frac{g_{a}}{g_{w}}-R_{a}}{-R_{w} \frac{g_{t}}{g_{w}}-w R_{a}+\pi} .
$$


The total effect on the gross wage rate is given by:

$$
\left.\frac{d w}{d a}\right|_{\substack{d R=0 \\ d \alpha=0}}=\frac{d w}{d a}+\left.\frac{d w}{d t} \frac{d t}{d a}\right|_{\substack{d R=0 \\ d \alpha=0}}=-\frac{g_{a}}{g_{w}}-\left.\frac{g_{t}}{g_{w}} \frac{d t}{d a}\right|_{d \alpha=0} .
$$

Substituting (A12) in (A13) yields

$$
\left.\frac{d w}{d a}\right|_{\substack{d R=0 \\ d \alpha=0}}=\frac{R_{a}\left[w g_{a}+g_{t}\right]-\pi g_{a}}{\left[-R_{w} \frac{g_{t}}{g_{w}}-w R_{a}+\pi\right] g_{w}}
$$

As the marginal tax revenues of the income tax are positive and $g_{w}>0$, the denominator is positive. Using (A3), it follows immediately that the second term of the right-hand side is negative. Substituting (A3) and (A4) into the first term and using (4), we obtain

$$
\begin{aligned}
w g_{a}+g_{t} & =\frac{(N-L)}{w(1-t)^{2}}\left((1-\gamma(1-\alpha(1-s)))(w(1-t)+a)-(1-s) b^{n}\right) \\
& =\frac{(N-L)}{w(1-t)^{2}} \frac{\left(w(1-t)+a-b^{i}\right)}{u}>0 .
\end{aligned}
$$

As $R_{a}<0$ the first term is negative as well and it follows unambiguously that

$$
\left.\frac{d w}{d a}\right|_{d R=0}<0
$$

\section{Appendix 5: comparing reforms}

The partial derivative of the trade union objective function (5) with respect to workfare enforcement $\alpha$, the workers' tax credit $a$, the income tax rate $t$, and the average equilibrium wage rate $\bar{w}=w$ are (Note that $\left.V_{w^{i}}=0\right)$ :

$$
\begin{gathered}
V_{\alpha}=\frac{\partial b^{i}}{\partial \alpha}\left(N^{i}-L^{i}\right)=-u \gamma(1-s)(w(1-t)+a)\left(N^{i}-L^{i}\right)<0, \\
V_{a}=L^{i}+\frac{\partial b^{i}}{\partial a}\left(N^{i}-L^{i}\right)=L^{i}+(1-u(1-\gamma(1-\alpha(1-s))))\left(N^{i}-L^{i}\right)>0, \\
V_{t}=-w L^{i}+\frac{\partial b^{i}}{\partial t}\left(N^{i}-L^{i}\right)=-w L^{i}-w(1-u(1-\gamma(1-\alpha(1-s))))\left(N^{i}-L^{i}\right)=-w V_{a}<0,
\end{gathered}
$$




$$
\begin{gathered}
V_{w}=\frac{\partial b^{i}}{\partial w}\left(N^{i}-L^{i}\right)=(1-t)(1-u(1-\gamma(1-\alpha(1-s))))\left(N^{i}-L^{i}\right) \\
+\frac{L_{w}}{N}\left\{(1-\gamma(1-\alpha(1-s)))(w(1-t)+a)-(1-s) b^{n}\right\}\left(N^{i}-L^{i}\right) .
\end{gathered}
$$

Substituting in the definition for the aggregate unemployment rate, the first term of (A18) can be rewritten as:

$$
\begin{aligned}
& (1-t)(1-u(1-\gamma(1-\alpha(1-s))))\left(N^{i}-L^{i}\right) \\
& =(1-t)\left(N^{i}-L^{i}\right)-\frac{(N-L)}{N}(1-\gamma(1-\alpha(1-s)))(1-t)\left(N^{i}-L^{i}\right) .
\end{aligned}
$$

Using the same reformulation as in (A14) and then using (6), the second term becomes

$$
\begin{aligned}
& \frac{L_{w}}{N}\left[(1-\gamma(1-\alpha(1-s)))(w(1-t)+a)-(1-s) b^{n}\right]\left(N^{i}-L^{i}\right) \\
& =\frac{L}{w(N-L)} \eta\left(w(1-t)+a-b^{i}\right)\left(N^{i}-L^{i}\right)=\frac{-L}{(N-L)}(1-t)\left(N^{i}-L^{i}\right) .
\end{aligned}
$$

Substituting (A19) and (A20) in (A18) allows us to sign $V_{w}$ :

$$
V_{w}=\frac{\left(N^{i}-L^{i}\right)}{(N-L)}\left\{(N-2 L)(1-t)-\left(\frac{(N-L)^{2}}{N}\right)(1-\gamma(1-\alpha(1-s)))(1-t)\right\}<0 .
$$

Now we have

$$
\begin{aligned}
& \left.\frac{d V}{d \alpha}\right|_{\substack{d R=0 \\
d t=0}}-\left.\frac{d V}{d \alpha}\right|_{\substack{d R=0 \\
d a=0}}=V_{\alpha}+V_{w}\left(\frac{d w}{d \alpha}+\left.\frac{d w}{d a} \frac{d a}{d \alpha}\right|_{d R=0} ^{d R=0}\right)+\left.V_{a} \frac{d a}{d \alpha}\right|_{\substack{d R=0 \\
d t=0}} \\
& -V_{\alpha}-V_{w}\left(\frac{d w}{d \alpha}+\left.\frac{d w}{d t} \frac{d t}{d \alpha}\right|_{\substack{d R=0 \\
d a=0}}\right)-\left.V_{t} \frac{d t}{d \alpha}\right|_{\substack{d R=0 \\
d a=0}} \\
& =\left.\left(V_{w} \frac{d w}{d a}+V_{a}\right) \frac{d a}{d \alpha}\right|_{\substack{d R=0 \\
d t=0}}-\left.\left(V_{w} \frac{d w}{d t}+V_{t}\right) \frac{d t}{d \alpha}\right|_{\substack{d R=0 \\
d a=0}} .
\end{aligned}
$$

Noting that the second term in brackets in the last line is negative and the change in the tax credit due to an increase in the degree of workfare enforcement is positive, we can obtain the following condition by using (11) again: 


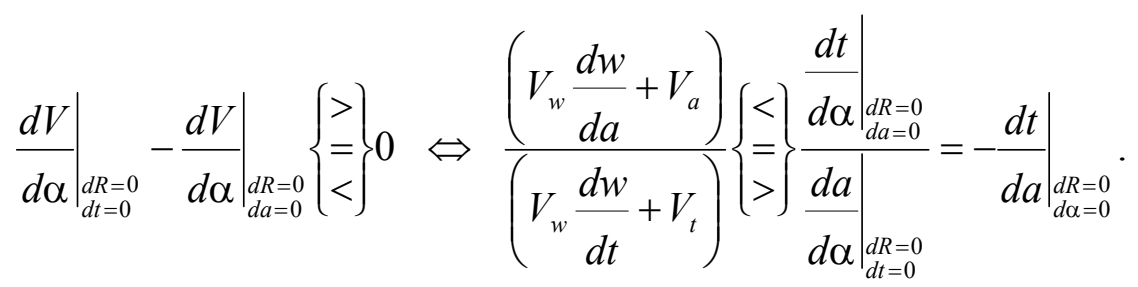

Using (A7), (A11) and (A16) this can be rewritten as:

$$
\left.\frac{d V}{d \alpha}\right|_{\substack{d R=0 \\
d t=0}}-\left.\frac{d V}{d \alpha}\right|_{\substack{d R=0 \\
d a=0}}\left\{\begin{array}{l}
> \\
= \\
<
\end{array}\right\} 0 \Leftrightarrow \frac{V_{w} \frac{g_{a}}{g_{w}}-V_{a}}{V_{w} \frac{g_{t}}{g_{w}}+w V_{a}}\left\{\begin{array}{l}
< \\
= \\
>
\end{array}\right\} \frac{R_{w} \frac{g_{a}}{g_{w}}-R_{a}}{R_{w} \frac{g_{t}}{g_{w}}+w R_{a}-\pi} .
$$

Multiplying through, noting that the left denominator is positive while the right one is negative $\left(g_{w}<0\right)$ :

$$
\left.\frac{d V}{d \alpha}\right|_{d R=0}-\left.\frac{d V}{d \alpha}\right|_{\substack{d R=0 \\
d a=0}}\left\{\begin{array}{l}
> \\
= \\
<
\end{array}\right\} 0 \Leftrightarrow\left(V_{w} R_{a}-V_{a} R_{w}\right)\left(w g_{a}+g_{t}\right)-\pi\left(V_{w} g_{a}-V_{a} g_{w}\right)\left\{\begin{array}{l}
> \\
= \\
<
\end{array}\right\} .
$$

Checking the signs in (A3), (A4), (A6), (A16), (A17) and (A13), it can be seen that

$$
\left(V_{w} R_{a}-V_{a} R_{w}\right)\left(w g_{a}+g_{t}\right)-\pi\left(V_{w} g_{a}-V_{a} g_{w}\right)>0 .
$$

qed. 


\section{References}

Besley, T. J. and S. T. Coate (1992): "Workfare versus Welfare: Incentive Arguments for Work Requirements in Poverty-Alleviation Programs," American Economic Review 82, 249-261.

Cancian, M., R. Haveman, D. Meyer and B. Wolfe (2000): Before and After TANF. The Economic Well-Being of Women Leaving Welfare, Institute for Research on Poverty Special Report No. 77, Madison, May.

Clark, A. E. and A. J. Oswald (1994): "Unhappiness and Unemployment", Economic Journal 104, 648-659.

Congressional Research Service (2000): Green Book 2000, Washington, D.C.

Daveri, F. and G. Tabellini (2000): "Unemployment, Growth and Taxation in Industrial Countries", Economic Policy 30, 47-104.

Gerlach, K. and G. Stephan (1996): "A Paper on Unhappiness and Unemployment in Germany", Economics Letters 52, 325-330.

Holmlund, B., K.-G. Löfgren and L. Engström (1989): Trade Unions, Employment, and Unemployment Duration, Clarendon Press: Oxford.

Layard, R., S. Nickell and R. Jackman (1991): Unemployment. Macroeconomic Performance and the Labor Market, Oxford University Press: Oxford.

Nickell, S. and R. Layard (1999): "Labor Market Institutions and Economic Performance", in O. Ashenfelter and D. Card (eds.): Handbook of Labor Economic Vol. 3C, Elsevier: Amsterdam et al., 3029-3084.

Schöb, R. (2000): Steuerreform und Gewinnbeteiligung, Mohr Siebeck: Tübingen.

Winkelmann, L. and R. Winkelmann (1995): "Happiness and Unemployment: A Panel Data Analysis for Germany," Konjunkturpolitik 41, 293-307. 


\section{CESifo Working Paper Series}

(for full list see www.cesifo.de)

877 Robin Boadway and Jean-François Tremblay, Public Economics and Startup Entrepreneurs, February 2003

878 Erkki Koskela and Roope Uusitalo, The Un-Intended Convergence: How the Finnish Unemployment Reached the European Level, February 2003

879 Robert Fenge and Volker Meier, Pensions and Fertility Incentives, February 2003

880 Eytan Sheshinski, Note on Income Taxation and Occupational Choice, February 2003

881 A B Atkinson, Income Inequality in OECD Countries: Data and Explanations, February 2003

882 Thomas Gehrig and Rune Stenbacka, Venture Cycles: Theory and Evidence, February 2003

883 Ralf Becker and Thomas Hellmann, The Genesis of Venture Capital - Lessons from the German Experience, March 2003

884 Eytan Sheshinski, Note on the Optimum Pricing of Annuities, March 2003

885 Paul De Grauwe and Magdalena Polan, Globalisation and Social Spending, March 2003

886 F. van der Ploeg, Do Social Policies Harm Employment and Growth?, March 2003

887 Mirjam van Praag, Initial Capital Constraints Hinder Entrepreneurial Venture Performance: An empirical analysis, March 2003

888 Bernard Steunenberg, Coordinating Sectoral Policymaking: Searching for Countervailing Mechanisms in the EU Legislative Process, March 2003

889 Eytan Sheshinski, Optimum Delayed Retirement Credit, March 2003

890 Frederick van der Ploeg, Rolling Back the Public Sector - Differential effects on employment, investment and growth, March 2003

891 Paul De Grauwe and Marc-Alexandre Sénégas, Monetary Policy in EMU when the Transmission is Asymmetric and Uncertain, March 2003

892 Steffen Huck and Kai A. Konrad, Strategic Trade Policy and the Home Bias in Firm Ownership Structure, March 2003

893 Harry Flam, Turkey and the EU: Politics and Economics of Accession, March 2003 
894 Mathias Hoffmann and Ronald MacDonald, A Re-examination of the Link between Real Exchange Rates and Real Interest Rate Differentials, March 2003

895 Badi H. Baltagi, Espen Bratberg, and Tor Helge Holmås, A Panel Data Study of Physicians' Labor Supply: The Case of Norway, March 2003

896 Dennis C. Mueller, Rights and Citizenship in the European Union, March 2003

897 Jeremy Edwards, Gains from Trade in Tax Revenue and the Efficiency Case for Trade Taxes, March 2003

898 Rainer Fehn and Thomas Fuchs, Capital Market Institutions and Venture Capital: Do They Affect Unemployment and Labour Demand?, March 2003

899 Ronald MacDonald and Cezary Wójcik, Catching Up: The Role of Demand, Supply and Regulated Price Effects on the Real Exchange Rates of Four Accession Countries, March 2003

900 R. Selten, M. Schreckenberg, T. Pitz, T. Chmura, and S. Kube, Experiments and Simulations on Day-to-Day Route Choice-Behaviour, April 2003

901 Stergios Skaperdas, Restraining the Genuine Homo Economicus: Why the Economy Cannot be Divorced from its Governance, April 2003

902 Yin-Wong Cheung, Menzie D. Chinn, and Antonio Garcia Pascual, What Do We Know about Recent Exchange Rate Models? In-Sample Fit and Out-of-Sample Performance Evaluated, April 2003

903 Mika Widgrén, Enlargements and the Principles of Designing EU - Decision-Making Procedures, April 2003

904 Phornchanok Cumperayot, Dusting off the Perception of Risk and Returns in FOREX Markets, April 2003

905 Kai A Konrad, Inverse Campaigning, April 2003

906 Lars P. Feld and Stefan Voigt, Economic Growth and Judicial Independence: Cross Country Evidence Using a New Set of Indicators, April 2003

907 Giuseppe Bertola and Pietro Garibaldi, The Structure and History of Italian Unemployment, April 2003

908 Robert A.J. Dur and Otto H. Swank, Producing and Manipulating Information, April 2003

909 Christian Gollier, Collective Risk-Taking Decisions with Heterogeneous Beliefs, April 2003

910 Alexander F Wagner, Mathias Dufour, and Friedrich Schneider, Satisfaction not Guaranteed - Institutions and Satisfaction with Democracy in Western Europe, April 2003 
911 Ngo Van Long, Raymond Riezman, and Antoine Soubeyran, Trade, Wage Gaps, and Specific Human Capital Accumulation, April 2003

912 Andrea Goldstein, Privatization in Italy 1993-2002: Goals, Institutions, Outcomes, and Outstanding Issues, April 2003

913 Rajshri Jayaraman and Mandar Oak, The Signaling Role of Municipal Currencies in Local Development, April 2003

914 Volker Grossmann, Managerial Job Assignment and Imperfect Competition in Asymmetric Equilibrium, April 2003

915 Christian Gollier and Richard Zeckhauser, Collective Investment Decision Making with Heterogeneous Time Preferences, April 2003

916 Thomas Moutos and William Scarth, Some Macroeconomic Consequences of Basic Income and Employment Subsidies, April 2003

917 Jan C. van Ours, Has the Dutch Miracle Come to an End?, April 2003

918 Bertil Holmlund, The Rise and Fall of Swedish Unemployment, April 2003

919 Bernd Huber and Marco Runkel, Optimal Design of Intergovernmental Grants under Asymmetric Information, April 2003

920 Klaus Wälde, Endogenous Business Cycles and Growth, April 2003

921 Ramon Castillo and Stergios Skaperdas, All in the Family or Public? Law and Appropriative Costs as Determinants of Ownership Structure, April 2003

922 Peter Fredriksson and Bertil Holmlund, Improving Incentives in Unemployment Insurance: A Review of Recent Research, April 2003

923 Bernard M.S. van Praag and Adam S. Booij, Risk Aversion and the Subjective Time Discount Rate: A Joint Approach, April 2003

924 Yin-Wong Cheung, Kon S. Lai, and Michael Bergman, Dissecting the PPP Puzzle: The Unconventional Roles of Nominal Exchange Rate and Price Adjustment, April 2003

925 Ugo Trivellato and Anna Giraldo, Assessing the 'Choosiness' of Job Seekers. An Exploratory Approach and Evidence for Italy, April 2003

926 Rudi Dornbusch and Stanley Fischer, International Financial Crises, April 2003

927 David-Jan Jansen and Jakob de Haan, Statements of ECB Officials and their Effect on the Level and Volatility of the Euro-Dollar Exchange Rate, April 2003

928 Mario Jametti and Thomas von Ungern-Sternberg, Assessing the Efficiency of an Insurance Provider - A Measurement Error Approach, April 2003 
929 Paolo M. Panteghini and Guttorm Schjelderup, Competing for Foreign Direct Investments: A Real Options Approach, April 2003

930 Ansgar Belke, Rainer Fehn, and Neil Foster, Does Venture Capital Investment Spur Employment Growth?, April 2003

931 Assar Lindbeck, Sten Nyberg, and Jörgen W. Weibull, Social Norms and Welfare State Dynamics, April 2003

932 Myrna Wooders and Ben Zissimos, Hotelling Tax Competition, April 2003

933 Torben M. Andersen, From Excess to Shortage - Recent Developments in the Danish Labour Market, April 2003

934 Paolo M. Panteghini and Carlo Scarpa, Irreversible Investments and Regulatory Risk, April 2003

935 Henrik Jacobsen Kleven and Claus Thustrup Kreiner, The Marginal Cost of Public Funds in OECD Countries. Hours of Work Versus Labor Force Participation, April 2003

936 Klaus Adam, George W. Evans, and Seppo Honkapohja, Are Stationary Hyperinflation Paths Learnable?, April 2003

937 Ulrich Hange, Education Policy and Mobility: Some Basic Results, May 2003

938 Sören Blomquist and Vidar Christiansen, Is there a Case for Public Provision of Private Goods if Preferences are Heterogeneous? An Example with Day Care, May 2003

939 Hendrik Jürges, Kerstin Schneider, and Felix Büchel, The Effect of Central Exit Examinations on Student Achievement: Quasi-experimental Evidence from TIMSS Germany, May 2003

940 Samuel Bentolila and Juan F. Jimeno, Spanish Unemployment: The End of the Wild Ride?, May 2003

941 Thorsten Bayindir-Upmann and Anke Gerber, The Kalai-Smorodinsky Solution in Labor-Market Negotiations, May 2003

942 Ronnie Schöb, Workfare and Trade Unions: Labor Market Repercussions of Welfare Reform, May 2003 